\title{
Capitalizing on Bare Life: Sovereignty, Exception, and Gender Politics
}

\author{
Jennifer Fluri \\ Geography Department and Women's and Gender Studies Program, \\ Dartmouth College, Hanover, NH, USA; \\ jennifer.fluri@dartmouth.edu
}

\begin{abstract}
This article examines the capital value of bare life as part of aid/development in (post)Taliban Afghanistan. I argue that the political production and spatial fixity of homo sacer "as the object of aid and protection" within specific geographic locations subsequently territorializes gendered bodies as a site for capital accumulation and exchange value through aid/development allocation. This occurs through a continual discursive reduction of "full or proper" human life to the remnants of bare life. This subjective reduction subsequently elicits capitalist-modernity as a prime method for rescuing bare life and transferring it to an image (and imaginary) of western political and economic life. Gendered multiplicities of bare life emerge from variant forms of political and economic opportunity among aid/development workers and Afghan recipients. I argue that the discursive framing of bare life is situated as a site for (re)constructing rights through "western" frameworks infused with geopolitical and economic exchange value.
\end{abstract}

Keywords: bare life, geopolitics, aid/development, Afghanistan, neoliberal capital, gender politics

\section{Introduction}

This article examines gender-geo-politics in Afghanistan by drawing on critical aid/development studies, Agamben $(1995,2005)$, and empirical research in Afghanistan. The politics and economics of bare life as tools of aid/development are well researched (Gregory 2004; Mitchell 2006; Petchesky and Laurie 2007; Sylvester 2006). This paper adds to this literature by analyzing the methods used to shape gendered bodies into objects of aid that are discursively placed as a perpetual site of potentiality. I argue against positioning bare life as political descriptor for conflict zone bodies and propose including a more thorough representation of the full, complex, social and political lives in these zones. Families, community, and other collectives living in conflict spaces reconfigure their lives as full and counter to the discursive and material attempts to reduce their human corporeality to a site stripped bare.

In order to set the context for this critique I begin with a review of the relevant literature in critical development studies and provide a historical overview of the geopolitics of aid/development in Afghanistan. This is followed by a discussion of (post)Taliban Afghanistan, field research methods, Agamben and relevant literature on spatializing exception and bare life. This article concludes by critiquing the 
discursive framing of bare life and calling for alternative representations of life in conflict spaces.

\section{Development Paradigms and Practice}

Critiques of development policy and practice emphasize the increased role of neoliberal economics, uneven resource allocations, and the politicization of aid to ensure donor strength and recipient weakness, which includes the assumptive descriptor of international aid/development workers as "experts" (Bondi and Laurie 2005; Kothari 2005; McKinnon 2000). The uneven geographies of modernity, global divisions of labor, and hierarchies of power re-situate knowledge by examining the tensions between universal claims of modern development as "progress" and the specifics that shape both complimentary and contradictory engagements between donors and recipients.

Critical scholarship also questions the ability (or desire) of humanitarian assistance to act impartially and whether it should assist in furthering certain "universal" human rights standards or geopolitical expectations (Atmar 2001; Duffield 2001; Leebaw 2007). Several studies identify the increase in non-government organizations (NGOs) and the growing fusion between security, violence, reconstruction, and development as part of rather than separate from politics (Duffield 2001; Hardt and Negri 2004; Goodhand 2006). The racial and orientalist configuration of aid during and directly after conflict are key components that help shape aid/development policies, and often include military intervention as a "necessary" component of peace building or humanitarianism (Denike 2008; Douzinas 2007; Woodward 2001). For example, US aid/development was politicized as "structural conflict prevention" amid growing criticism at the end of the cold war (Duffield 2001:120). Contemporary international aid/development has become a massive transnational business soliciting monetary and sociopolitical capital from various organizations and donor countries (Goodhand 2006).

Gender analyses also emphasize the integration of hierarchal relations into the structures of development organizations (Kabeer 1994). Similarly, critiques of transnational feminist networks identify parallel racial or socioeconomic status as commonalities between women's groups (across geographic divides) in solidarity against patriarchy, while simultaneously marginalizing the needs and experiences of women in lower socioeconomic classes and minority or marginalized racial and ethnic groups (Alarcon et al 1999; Mohanty 2004; Naghibi 2007).

Additional studies provide critical insights and analysis of gendered development paradigms, such as, micro-credit programs, the United Nations, women-focused economic policies, and post-development projects; while strategizing solutions grounded in grassroots and post-structuralist feminisms that counter neoliberal ideologies (Benería 2003; Jaquette and Summerfield 2006; Kabeer 1994; Sangtin Writers and Nagar 2006; Saunders 2002). The increase in development projects and paradigms demonstrates the cyclical trajectories and processes of gendered development as both akin to modernization ideologies and a growing part of the neoliberal global capitalist economy (Benería 2003; Coleman 2007; Katz 2004; Oza 2006). 
Critical scholarship on international development highlights the powerful role of gendered hierarchies, uneven economic practices, and neoliberal geopolitics as central to development policy and practice in recent decades. The following section outlines the history of international aid/development in Afghanistan and its associated links to modernization and gender geo-politics.

\section{Afghanistan: Modernization, Gender Politics, Geopolitics, and Conflict}

Throughout the twentieth century, Afghanistan's central leadership initiated several modernization and reform efforts, which were funded and influenced by outside powers. King Amanullah (1919-1929) instituted several modernization projects modeled after the western European influences in Iran under Reza Shah and Turkey under Mustafa Kemal Ataturk. His efforts were met with resistance through a series of rebellions eventually forcing him into exile in 1929. This was followed by the rule of Muhammad Nadir Shah until his assassination in 1933, followed Afghanistan's last twentieth-century monarch, King Zahir Shah (1933-1973). Zahir Shah's reign included several phases of modernization and competing international influences. Prior to World War I the monarchy sought international assistance from countries that would create the least disruption locally. In the post World War II era, Afghanistan received the bulk of international assistance from the Soviet Union and the United States, resulting in massive development projects such as a national highway system and large-scale dams (Dupree 1980; Rubin 2002). King Zahir Shah's cousin Muhammed Daud, in his capacity as prime minister (1953-1963), ushered in many education and civil reforms, which relied on foreign aid. Part of his efforts included reforms that focused on women's education, presence, and participation in public life, all of which were limited to the capital city, Kabul.

King Zahir Shah, after Daud's decade as prime minister (1953-1963), ushered in a constitutional monarchy and sought to provide equal rights to women (1964 constitution), increasing their educational and employment opportunities, which remained limited to Kabul city elites (Rubin 2002; Zulfacar 2006). Urban education included the growth of middle income and intellectual classes with several divergent international influences. ${ }^{1}$

The Peoples Democratic Party of Afghanistan (PDPA), founded in 1965, became a leading Marxist-intellectual and political organization. This party would later usher in the communist state. First, former Prime Minister, Muhammad Daud, ousted his cousin, King Zahir Shah from power in a bloodless coup in 1973. Daud declared Afghanistan a republic with himself as president. He jockeyed for power by integrating international interests with local communists and Islamic intellectuals. The fractional PDPA (later renamed the Democratic Republic of Afghanistan-DRA) united in 1975 under a weak coalition that led to the Saur (April) Revolution in 1978 , resulting in the death of Daud and the beginning of the communist state, with Muhammad Taraki² as leader (Roy 1994; Rubin 2002).

The DRA sought to extend their political ideologies from Kabul city to the rural provinces. This took the shape of several reform efforts throughout the country. Gender-based reforms and changes to the existing land tenure system received the 
most resistance from provincial/tribal authorities (Rubin 2002). By July 1978, the social and political reforms focusing on women's rights were largely abandoned. This was also precipitated by infighting between the two factions (Parcham-masses and Khalq-banner) of the DRA, which led to the ousting of Parcham leaders from government, including Anahita Ratebzad, a primary women's rights advocate (Edwards 1987). DRA infighting, local uprising, and Soviet manipulation led to the Soviet invasion in 1979. Babrak Karmal became president and secretary general of communist Afghanistan from 1980 to 1986, followed by Najibullah. ${ }^{3}$ Resistance to the Soviet invasion took many forms both in and outside of Kabul. Seven separate Sunni Islamic groups dominated the resistance due to the large amount of international assistance provided by the USA and Saudi Arabia, with weapons distribution through Pakistan. Humanitarian aid and assistance provided by the USA to refugees in Pakistan was used as a method for gaining local support for various Soviet-resistance factions (Barfield 2004).

After the military withdrawal of Soviet troops in 1989, the Soviet Union continued to support the government in Kabul led by President Najibullah, while the USA provided financial support to several Mujahidin factions (Goodhand 2004). After the fall of the Soviet Union (1991) and the subsequent fall of the Najibullah government (1992), aid functioned largely outside direct geopolitical control, as the former Soviet Union and USA discontinued major sources of funding to Afghanistan. A civil war (1992-1996) erupted between the fractional Mujahidin groups after the fall of Najibullah. International aid was not directly politicized by state intervention; however, competition grew among aid groups and included a distinct lack of accountability and oversight.

The growth of the Taliban movement in southern Afghanistan (1994) and the eventual takeover of the central government in Kabul (1996) ushered in a new area of politicized aid. Aid was used as a method to alter Taliban behavior; however, humanitarian organizations remained unsuccessful in their attempts to coerce the Taliban (Barakat and Wardell 2002). In Afghanistan, aid agencies invoked human rights discourses to define their own agendas by assuming a common ground of ideologies. However, during the Taliban period, "much energy was spent on widening the gaps between 'them' and 'us' as on working towards a common cause" (Johnson and Leslie 2002:76). Thus, claims of "universal" rights fell short as they stemmed from western concepts of individualism; while in Afghanistan the most fundamental relationships are constituted within the immediate family and an extended network of kinship relations (Johnson and Leslie 2002). Current international influences and western ideologies seeking to modernize Afghanistan remain subject to these historic liabilities (Rashid 2008; Suhrke 2007).

The various phases of modernization, development, and militarization of Afghanistan illustrate various international influences on the central government in Kabul throughout the twentieth century. Despite divergent approaches, there are common themes, including women as a symbol of modernity or tradition respectively (Suhrke 2007). Afghan politics continually circled around "gendered ideals of personal integrity", and power dynamics that initiated control over women's lives (Edwards 2002:172). Since the communist coup, encroachments into Afghan tribal autonomy, either by the central government, Soviet Union, or 
non-Afghan Islamic leaders (from the pan-Islamic jihad factions of the Mujahidin), continually overstepped the limits of legitimate authority through domestic violation and emasculation (Edwards 2002:173).

These historic precursors, in many respects, mark international intervention in the contemporary era. Several policy reports and academic analyses identify the limitations and ineffectiveness of international programs that attempt to liberate Afghan women (or improve their lives). These limitations include a lack of understanding; Afghanistan's gendered political history, family dynamics at the household scale, and the importance placed on community autonomy (Abirafeh 2009; Azarbaijani-Moghaddam 2006, 2009; Kandiyoti 2007). Contemporary international aid and development projects in Afghanistan are further politicized by security-driven aid agendas and militarized reconstruction efforts (Johnson and Leslie 2004; Shannon 2009). The spatial imprint of international organizations on the capital city and the dual and auxiliary economies that result from top-heavy aid/development inputs are also important to note (Fluri 2009). The privatization of aid in Afghanistan is arguably central to the lack of coordination and accountability associated with international development projects. Capitalizing on the suffering or "lack" of ability associated with Afghanistan's people through discursive labeling remains a significant aspect of international intervention that requires further inquiry and critique. In the next section, I provide an overview of my empirical research methods and description of the "field" in Kabul, Afghanistan followed an overview of Agamben's $(1995,2005)$ theories on the state of exception, homo sacer and bare life, in order to examine the capitalization of bare life as part of the gender geo-politics of international intervention in Afghanistan.

\section{Research Methods}

The data for this article were collected during three field site visits to Kabul, Afghanistan (summer 2006, winter 2007, summer 2008). This research examined international workers and Afghan nationals by way of qualitative inquiry. This included observing the spatial interactions and separations among and between international workers and Afghan citizens living in the capital city, and the impacts of neoliberal geopolitics (see Roberts, Secor and Sparke 2003). Additionally, field research included qualitative surveys, interviews, and focus groups with international workers $^{4}$ and interviews with Afghans living in Kabul city and working with internationals in various capacities.

The international workers participating in this study self-identified themselves as modern/western (using these terms interchangeably) and in general defined western modernity as preferable and progressive in contrast to the "traditional/conservative" Afghanistan (also see Davis 2005; Kabeer 1994). All interviews with internationals were conducted in English, which is also the primary language of communication among international workers. ${ }^{5}$ Interviews and discussions with Afghan respondents were conducted in English and Afghan-Dari or Pashto with the help of local research assistants. The empirical information included in this paper was also drawn from informal discussions with and observations of workers (both Afghan and International) in places such as restaurants, shopping 
centers and hotels that cater to internationals. My positionality as an international researcher provided me with increased access to international spaces (not accessible to Afghans) and "insider" information. Conversely, I remain an outsider as someone not involved in aid/development or private sector investment. This analysis is therefore informed by my insider/outsider position among international workers, and outsider position in relation to Afghan families and communities.

\section{Kabul City (Post)Taliban}

Kabul city, after the fall of the Taliban and implementation of the Karzai-led interim (and later "elected") government, ${ }^{6}$ quickly developed into a central site for international work and workers. Many international governments reconstituted their embassies and set up aid/development projects. Also by 2005 there were over 2400 registered NGOs from over 40 countries. The arrival of well-funded government and non-government aid and development organizations increased the "need" for private contractors, logistics, and security companies. The private sector grew as funds increased for these services. With the influx of aid dollars the war economy included significant profits for many organizations and workers within the international sector. Workers within large aid/development organizations (both government and non government) received considerably high salaries ${ }^{7}$ that included danger pay and housing allowances as incentives for working "in country" (Fluri 2009). Many aid/development and private sector organizations operate projects throughout Afghanistan with Kabul as an operational base. The extensive amount of international aid/development funding is led by the US government as the largest donor country, and the United Nations Assistance Mission in Afghanistan (UNAMA) (as well as other UN branches) followed by several EU donor countries, all with divergent geopolitical interests. This flood of aid money and international personnel "developed" Kabul city into a place that caters to the technological and logistical "needs" as well as the social comforts and desires of international workers (Fluri 2009).

Kabul city residents (both international and Afghan) are comprised of a diverse array of ethnicities (and nationalities), languages, religious beliefs, socioeconomic class, education levels, and experiences. Afghanistan's heterogeneous society includes 50 ethnic groups (Pashtuns are the largest followed by Tajik, Uzbek, and Hazara). There are two official national languages-Pashtu and Dari-with Turki ranked third as a widely spoken language (which includes Uzbek, Turkoman, and Qirghiz), followed by nearly 30 minority languages and dialects (Adamec 2003; Rubin 2002). Gender roles, norms and relations also vary by and within ethnic groups, and by family, location, socioeconomic class, and education level. A decisive urban/rural split exists between one's educational opportunities and access to certain resources.

In considering critical aid/development scholarship and Afghanistan's history, I focus specifically on (post)Taliban aid/development practice in order to illustrate the capital accumulation associated with gendered bodies in the geopolitical aftermath of "operation enduring freedom". Agamben's $(1995,2005)$ state of exception, homo sacer, and bare life provide a useful entry point for situating the "western" 
geographic image of Afghans. I argue that capital sent to Afghanistan for the purposes of international "assistance" (and geopolitical strategy) assumed the social reproductive aspects of everyday human lives (in Afghanistan) as bare life, requiring "aid/development" intervention. This form of reductionism objectifies bodies and experience as continually expectant of need. The gendered body of bare life represents the site from which to re-inscribe and conceptualize a "full life" as brought forth by "enlightened" internationals as a path to "freedom" through aid/development paradigms.

\section{Gendered Exceptional: Homo Sacer and Bare Life}

Agamben argues that a "zone of absolute indeterminacy" exists between anomie and law, which creates a spatial disjuncture or "single catastrophe" between the sphere of human life and the juridical order (Agamben 2005:57-58). The "saving" of Afghanistan from the "catastrophe" of the Taliban (as geopolitically framed by the USA) included a war of ambiguity between Afghanistan's victimized and volatile genders. The US desire to save Afghan women was a significant component for shaping the moral boundaries to justify the use of violence (Abu-Lughod 2002; Hunt 2002). Agamben's definition of homo sacer identifies a sacred body outside the juridical order that can be killed but not sacrificed and therefore killed with impunity (Agamben 1995). Conversely, Afghan women, identified as the exalted victims (of "our" enemy) are placed (at least at the level of discourse) as (sub)sovereign sacred subjects discursively targeted for saving rather than death. The female Afghan body's (sub)sovereignty manifests as both inclusive exclusion (exception), and exclusionary exclusivity, by her discursive geopolitical annexation from Afghan men. This exclusivity meets the invading country's savior fantasy through the rhetoric of bringing forth women's unveiling, freedom, and liberation.

In other words, Afghan women, targeted (by the USA) as (sub)sovereign sacred subjects are placed into the zone of indistinction through their victimized distinction. Afghan women identified by the USA as victims in need of a geopolitical savior are (dis)placed in various ways that attempt to discursively separate them from Afghan men by diminishing the diversity of women into a narrowly categorized and conceptualized "Afghan woman". Similarly, Afghan male diversity is reduced into a dichotomized representation of violent agency as either enemy combatants or potential allies_without victim status-(also see Hannah 2006).

Afghan women's agency, power, and position within Afghan politics, society, community, and kinship are marginalized from consideration in order to highlight their "liberation" through modern sovereignty as an act of economic and political "salvation". Thus, poor, rural, or illiterate Afghan women may be identified as the most needy based on development indicators (such as maternal mortality), while urban or educated women are imagined as hungry for capitalist-secular interventions and western feminist ideals. Often, international "expert" knowledge does not address the actual "needs" or concerns of women or provide a desirable outcome. For example, in the abstract, a woman's separation from her patriarchal family structure may provide her (in an ideal context) with sovereign-secular "freedoms". 
However, Afghan woman's citizenship and relationship to the Afghan state does not ensure her these "freedoms" or corresponding citizenship rights and securities. Thus, this separation would not provide her body with physical security (either in or outside her home) and disrupt rather than improve her position, influence, or power within her kinship network. In many rescue narratives, a space of ambiguity emerges between the potential benefits of inclusion and exclusion.

In order to further discuss this disjuncture, I turn to Agamben's discussion of the ban's double meaning. The ban "originally meant both 'at the mercy of' and 'out of free will, freely,' both 'excluded, banned,' and open and free to all' "(Agamben 1995:110). The double meaning of the ban illustrates the ambiguities between secular non-familial sovereignty as "freedom" and the structures of security, control, and protection provided within many Afghan kinship structures and networks. Both sovereignty and family life provide opportunities and challenges, which are imperfect and subject to fissures, dissent, and violence. The family subjectively perceived through modern "western eyes" as a site of control over women also ideally prevents the banishment of a woman's body. This occurs by visually signifying in public space ${ }^{8}$ that her body is under protection (and control) of her kinship group rather "open and free to all". Therefore, the honor of the family morphologizes women as the embodiment of family strength and autonomy from an outside power (such as a rival tribe, the Afghan state, or foreign states).

Conversely, women's bodies are key sites for the biopolitics of modernity by way of corporeal representation - "lifting the veil" —and (re)placement of the state as citizen protector. The state's encroachment into private spaces disrupts the expected boundary between the state and the autonomy of patriarchal family authority. International expectations attempt additional erosion of this boundary. In all cases women's bodies are ambiguously placed and must negotiate among these competing spheres of influence, opportunity, and (in)security. The tensions, double meanings and experiences of the ban illustrate the intricately woven complications that mark women's bodies as the representational fuel for biopolitics at multiple geopolitical scales.

The geopolitical focus on Afghan woman as a prime site for western-secular salvation as processed through aid/development and capital accumulation further engages the double ambiguities of the ban. To "save" Afghan women by way of neoliberal imperialist quasi-feminisms assumes women's empowerment and potential autonomy from patriarchal family structures through economic independence. Women's agency is often positioned as only available through secular modernity and democracy. However, as Mahmood argues "what may appear to be a case of deplorable passivity and docility from a progressive point of view, may actually be a form of agency — but one that can be understood only from within the discourses and structures of subordination that create the conditions of its enactment" (2005:15). Women's bargain with familial patriarchy (see Kandiyoti 1988) may be exchanged for a "new" bargain with capitalism, by way of her paid labor (usually outside the home), which does not in and of itself increase her agency or authority within the family. Conversely, banishment from home/family may be mitigated through violence (and in some cases death) in order to reaffirm family honor by way of sacrificing the woman's body (and life) and therefore restoring 
family strength, honor, and autonomous power. Women's bodies in these scenarios provide a significant site for social, political, and economic struggles associated with ideology, identity, or morality.

\section{Zones of Indistinction: Bare life and Biopolitical Development}

Agamben (1995) argues that the corpus represents a dualistic tension that on the one hand represents subjection to sovereign power, and on the other, an embodiment of individual liberties. He continues by stating that:

one of the essential characteristics of modern biopolitics ... is its constant need to redefine the threshold in life that distinguishes and separates what is inside from what is outside. Once it crosses over the walls of the oikos and penetrates more and more deeply into the city, the foundation of sovereignty-nonpolitical life-is immediately transformed into a line that must be constantly redrawn (Agamben 1995:131).

As argued by Edwards (2002) and Zulfacar (2006) the line between private spaces and public state (or foreign) intrusion into the heart of the khana (home-oikos), or qala (multigenerational home compound) continually occurs through the lives and bodies of women. This also disrupts their interlocked relations with and dependency on men in their kinship network.

When aid/development to the corpus intersects with securitized and militarized aspects of reconstruction and short-handed nation building, the line between political and nonpolitical lives slowly erases. Aid and development workers become political subjects embodied with concepts learned from their sovereign location's institutionalized education and further reinforced by "universal" human rights discourses. Human rights conceptualized in these contexts may be "ethically superior" to other theoretical rights-based frameworks but limited in their ability to orchestrate justice (Petchesky and Laurie 2007). Human rights theories, concepts, and transactions (as argued by several scholars) do not indeed represent the "universal", but rather an "invention" that is situational, focused on "western enlightenment" and notions of individualism, infused with Judeo-Christian belief structures, and based on capitalist economies (De Waal 1998; Forsythe 2005; Hancock 1989; Hunt 2007). In Afghanistan, these concepts often run counter to the organization and functionality of kinship structures (Johnson and Leslie 2004).

Agamben's articulation of bare life realized through the corpus provides the gendered site from which a set of capital, political, and social values are placed, accumulated, and disposed. The rights of the modern individual requires displacing a collectively based understanding of rights that may also counter individual rights, while the rights of citizens (as a collective body) are also separated (and differentiated) from the rights of "man" (see Agamben 1995:133). Citizens of a legitimate sovereign are thus ascribed with certain "rights" that are not equal to individuals outside the "protection" of the sovereign and defined only by way of their exception to these rights (Gregory 2004; Hannah 2006). Mitchell, in her review of Agamben's theoretical placement in geography, argues that the "Modern homo sacer is always already a woman. By 'woman' 
I mean any body scientifically constructed, classified and naturalized as different from the universal, stripped-down individual of modernity" (2006:103). This stripped down individual of modernity assumes a (re)constituted body from bare life to full "universally" recognized definitions of a modern life "worth living".

Sylvester (2006) discusses the intimacies and intricacies of homo sacer and bare life through literary accounts of the Rwandan genocide. She highlights the trading off of one form of death for another as an act of resistance to the prescriptive death of homo sacer: "One who is in it as homo sacer may try to control death by rewriting its script, substituting another biopolitics of exception for the one that was to be his fate" (2006:73). The fate associated with the stripping down and devaluation of life through the reduction of "good or full life" to bare life continually relies on a powerful perspective to determine a life worth living.

\section{Capital and Bare Life}

In the introduction to Homo Sacer, Agamben defines ancient Greek terms for life: "zoë which expressed the simple fact of living common to all living beings (animals, men, or gods), and bios, which indicated the form or way of living proper to an individual or a group" (Agamben 1995:1). He sets up these distinctions to critique the condition of modern "western" politics. "Western politics has not succeeded in constructing the link between zoë and bios, between voice and language, that would have healed the fracture. Bare life remains included in politics in the form of the exception" (Agamben 1995:11). Agamben also identifies sacred life, homo sacer, which is made into "the object of aid and protection" (1995:133). He continues to link humanitarian organizations "in perfect symmetry with state power, need. A humanitarianism separated from politics cannot fail to reproduce the isolation of scared life at the basis of sovereignty, and the camp" (1995:134).

Humanitarian organizations and development projects are integrated into the folds of sovereign power based on donor dictates and the ideologies of individuals on the "front lines" of humanitarian action. Also the assumption that life targeted for humanitarianism is by definition homo sacer and bare life assumes a hierarchal arrangement between zoë (bare life) and the subjective claims and politicized perspective for defining bios or proper life worth living. Placing (or displacing) life onto the margins of bios (proper life) by firmly binding it into a framework of human rights at the site of zoë (as common or bare life) subjectively defines and demarcates bare life as the site of living death, as well as potentiality or transference.

Minca's calls on geographers to think of places (rather than spaces) in order to avoid translating lived bodies into "the corpus of the nation" and the isolation of bare life (Minca 2007:90). Bare life (as defined in conflict or emergency aid/development zones) is life on the precipice of potentiality - as a living corpse "in need" of rebirth to bios through outside intervention. Layers of politics (and economically structured assumptions) substantiate the reduction from "proper" to bare life, and the creation of victims into sites of "humanitarian" biopolitics. As argued by Redfield: "the bios that understands itself as a civilizing force has difficulty imagining a zoë that it could not civilize or one whose alteration might change the very conditions of dignity" 
(2005:345). Bare life can then be discursively articulated as a site of potentiality through transcendental or metaphysical re-birth (such as attempted by religious groups) or by way of economic transference from bare life (zoë-essential life) to bios (life with meaning-a "proper" life). The transference from zoë to bios reevaluates life by way of its devaluation through an outsider's lens. Life defined as on the edge of survival-essential and basic_resides in this zone of indistinction, where "universal" conceptualizations of rights are called upon to carry out a rescue by means of economic development as the mode of this transference.

In interviews, focus groups, and observations of international workers in Kabul, participants regularly described Afghan lack of "capacity" as a central barrier to development. Conversely, many international workers also discussed the hospitality and kindness of Afghans in association with local cultural norms and for some as a conundrum to the continued situation of conflict:

I can sum it up by explaining what I think of Afghanistan. It is a very poor country, but very proud, and very hospitable. They have nothing and will give you the last scrap of food, but keep this in mind, because of cultural differences, they see you as a foreign infidel and if they can take something from you or rip you off then they will lose respect for you. It is a whole cultural thing (male private sector worker, USA, 42).

It's extremely conservative, but very welcoming. They respect the fact that I am not Afghan, but [the culture] ... well it is kind of crazy. Like the whole Pashtunwali, they will harbor enemies if you ask refuge, and they will turn on you if you screw up (female international development worker, USA, 26).

Afghan culture is a lot about artificial hospitality. People are not very open, though they pretend to be. Afghans don't appreciate closer interaction with outsiders and always maintain a distance. Hugging and kissing each other is quite superficial as people are not open. Afghans also take refuge in the name of religion and culture when they think that things are not happening the way they would like them to be (male international aid worker, UK, 25).

These quotes are included to help illustrate the ways in which international workers grapple with and attempt to interpret Afghan culture, while discussing their own difficulties of working within Afghanistan and meeting the mandates or expectations of their respective aid/development organizations. These included many paradoxical discussions about the positive and negative aspects of Afghan people along with profound frustration with what is commonly referred to as "Afghan lack of capacity".

Many participants also likened adult Afghans to children (or in some examples animals or sub-humans), to further underscore Afghan inabilities. Aid/development workers reduced Afghan full-adult-human life to child-like (or less than human) based on neoliberal economic frameworks. The following quotes exemplify the tenor of these discussions:

The best way to describe it [Afghanistan] is Afghans have the emotional level of a 13year-old. People will not and do not accept responsibility for anything both personally and nationally. It is always someone else's job to take care of things ... expectations are that you (internationals) must take care of things and that you have the capacity because you are a foreigner to take care of things and improve their situation, and now 
put that in the context of a 13-year-old and you have Afghanistan (female international development consultant, USA, 2006).

We have an utterly polarized relationship. "They" do not respect "us". "We" do not respect "them". We drive property prices through the roof: a minority benefits. We hire all the Pakistani returnees because they know a bit about computers and we speak English; we forget about the rest. Our projects aren't sustainable unless they are emergency interventions. We disappoint. To them, we are drunks, whores, and heretics. To us, they are incompetent, thieving, lazy, hopeless, abusive, and medieval (male aid worker, Italy, 2006).

They are like children in their capacity. I often think if we can put a man on the moon we should be able to teach an Afghan to think (female international development officer, USA, 2006).

Afghanistan is bereft of skilled workers in almost all sectors, especially management/administration/finance; and what a challenge this presents in trying to help things/people "develop". And, I would describe behavior and beliefs (to the extent that I understand them) and things that I admire (can't think of any) and things that I don't-girls can't get to school, for example (female international aid worker, France, 2006).

These quotes provide a small window into the macro discourses, projects, and policy of aid/development in Afghanistan, which includes multiple and often competing goals and agendas for "developing" Afghanistan within the neoliberal global capitalist structure. Additionally, these quotes (and similar ones) were largely from individuals who also stated strong and long-term personal commitments to "assist" Afghans towards their "modern" future.

These examples point to what Belcher et al (2008) identify as the topological spatializing of exception (which in this case) are displaced onto the bodies of Afghans as a prime site for the mobile zone of indistinction. Conflict zones and sites of displacement shape the perceptions of aid workers "whose interests are served by pathologizing, medicalizing, and labeling the refugees as helpless and vulnerable or alternatively as cheaters, schemers and obstacles of efficiency" (Petchesky and Laurie 2007:11). These perceptions create spatialized divisions and representation that attempt to remove refugees and conflict zone survivors from their continued bios to remnants of bare life. Belcher et al identify topological space as "not only emergent and governmental, but also always potential-that is, both capable of becoming and of not becoming" (2008:502, first emphasis mine, second original). The potentialities of zoë situate the site from which humanitarian aid/development are placed and where the value of life resonates as a site of capital accumulation in order to subjectively reverse the object of bare life to the political subject of bios. Capital exchange occurs through the transference from zoë to bios, as a mode of production. The value of life transferred (and its exchange rate) are evaluated and determined through the economic and political acts and actions of organizations and agencies (as defined by donors) from the "first to third world".

Part of ascribing value to zoë as separated from bios requires a disruption in order to place zoë outside a universal conception of human rights (or on its margins) in order to transfer zoë to its "proper" embodiment, as bios (a proper life worth 
living). Afghan women (and men), when labeled as homo sacer, existing in or at the margins of bare life, may not believe or identify their bios as reduced to bare life (by military or aid/development personnel). However, they also at times participate (and perform) in its inscription as a part of the ephemeral and expected exchange of so-called tradition for "modern re-birth". For example, discussions with Afghan men and women working within the international aid/development sector identified several problems associated with being discounted by international workers. They also discussed how they "know what to say" in relation to international perceptions of need, women's rights, and human rights in order to get the attention of aid workers. Other discussions with Afghans that worked with internationals and consumed international news about Afghanistan included concerns over the focus on war and suffering, rather than Afghan life and culture. For example, one respondent stated:

During the Taliban time, life was bad but not that bad as westerners say it was. We could not listen or play music at night so we told lots of jokes. To keep our spirits up we would sit together at night and tell each other jokes (Nazer, Afghan male, 2008).

Women in relative positions of power within the government and judiciary also expressed their dismay at several aid/development organizations working on "women's issues", while not listening to their suggestions or ideas for projects (also see Abirafeh 2009; Azarbaijani-Moghaddam 2009). The geopolitical focus on women in Afghanistan created several opportunities for both the aid/development organizations and Afghan women with the "appropriate" skills. Much of work in international offices requires the ability to speak English, use a computer, manage files, and translate. Many organizations actively seek to have Afghan women on staff either as part of the organization's goals and initiatives, or (more commonly) to increase its funding opportunities. The following quotes from interviews with international workers highlight the complications and opportunities associated with hiring Afghan women:

We cannot afford women like Janah. Women her age [late 20s] with even some English are hired by larger international NGOs, who can pay them more than double what we can pay. It is hard to keep women on staff, because once their skills improve they are off to the next job with more money, and how can you blame them (female Afghan-American volunteer, 2008).

Afghan women and all the attention they get has created an unbalanced economic situation here. There are less of them with education, English skills, and mobility outside the home, so they can fetch a high salary. Also, international organizations get more money when they have Afghan women workers or programs. So much of the focus has significantly helped to boost salaries and opportunities of a small number of women, while the majority receive little benefit (female international aid worker, UK, 2007).

You see I run a western office here [in Kabul]. I know right away, when an Afghan women comes in with her brother or father that I cannot work with her. If she cannot move about the city unescorted, she cannot work in this office. I need to have women who can do what we are trying to accomplish here (female international aid worker, USA, 2008). 
These quotes are included to demonstrate the general sentiments among aid/development workers about Afghan women's labor and value. Also, due to the limited number of Afghan women with "acceptable" office skills, ${ }^{9}$ there is a greater demand than supply of female staff. This has created increased pay for these Afghan women, and more flexible work schedules not generally afforded to Afghan men (with similar skill sets). Afghan women also supply a unit of capital accumulation because their presence and employment provide these organizations with the opportunity to broaden their funding opportunities, and subsequently increase the demand for women with these skills. Afghan women have therefore become a site of capital accumulation and exchange.

Trauma, war stories, and tales of abuse, forced marriage, and traditionalism are another unit of capital exchange. Several "best selling" books about Afghan women, written by internationals, exemplify the capital value placed on exchanging Afghan female suffering by way of international interlocutor's (non)fictional narratives (Whitlock 2007). Afghan women (and some men) are also solicited to exchange their memories of suffering to secure jobs, educational scholarships abroad, and other forms of capital solicitation. These acts resonate with what Spivak (1987) identifies as strategic essentialism, which in these cases solicits capital resources by way of exchanging essentialist notions of life in conflict. These representations often discount the different conditions and meanings of bare life as they intersect with cultural and place-based circumstances in addition to gender, sexuality and race/ethnicity (Petchesky and Laurie 2007:16). Many humanitarian aid organizations also solicit funds from donors through images of life on the edge of survival-bare life. Although, defined as an "effective" method for securing funds, it is also critiqued for commodifying suffering, while abstracting pain onto the body as image and object that is disconnected from material reality (Kennedy 2009). These examples question the "hierarchies of virtue" that engender certain lives, deaths, and suffering as deserving "savior" or serving as a unit for capital exchange (Mindry 2001; also see Butler 2004).

The (US-led) international categorization of Afghan women (in post911) geopolitical discourses dichotomized her life into nestled sound bites: political/private, tradition/modern, religious/secular. These binaries help to produce the capital value of "her" story and reinforce "traditional/religious/family life" as zoë (bare essential life) and modern as bios or "proper life". This further abstracts the complex materiality of everyday life and refashions the spaces of ambiguity and indistinction through a series of negotiations and contestations that represent her life as bare traditional religious, which must be re-made, modern proper bios.

Bare life reductionism engendered through the corpus and spatialized as the site from which to articulate rights also defines life's value, value(s), and collateralizes death. Bare life geopolitics, as discussed by Gregory (2004), is the locus of civilian death-killed with impunity and beyond the biopolitical reach of human rights or international law. However, we must be careful not to also reduce the places of life and death in conflict zones to the spaces of bare life (Minca 2007). The economics of bare life rely on this reductionism. The spatializing of exception illustrates a continual 
topology of bodies as the objects of bare life rather than subjects of bios in the midst of conflict.

Bare life economics rescale geopolitics by intimately conceptualizing the body as a site from which to articulate human rights' most basic and hierarchically situate capital value, through the development "expert". Thus, western discourses focus on the abusive or "dark side" of Afghan traditions or family life, while forgetting (or not acknowledging) other aspects such as social reproduction and interactions, humor and the fulfillment of (women's and men's) lives within their families.

The reduction of civilian lives (in conflict zones) to zoë may also be economized through death, such as the military collateralization of civilian bodies. Remittances paid to the families of civilians killed by US coalition forces exemplify the monetary value placed on death, in contrast to civilian life (see Olds, Sidaway and Sparke 2005). This form of economic value acts as another reductive layer of civilian life to a mere sum of collateral-capital value. In conflict zones, women's and children's lives become the nucleus of life most basic and bare. Their deaths are highlighted in political actions by virtue of the apolitical framing as agent-less victims-while simultaneously politicizing their bodies as the corpus in need of protection by force at different politically constructed scales (local, national, or international). Their bare life is predefined through their vulnerability to violence and assumed lack of bios. This biopolitical gendering of need underscores the political weight of savior/protection claims for a variety of actors at a number of geopolitical scales (home, community, region, state/nation, international). However, as discussed by several feminist scholars, gender savior mythologies have been a continual aspect of war-based gender binaries that do not serve to improve women's lives or political agency (Cockburn 2001; Enloe 1989, 2000). Additionally, saving or protection from an outside State often masks violence perpetrated by the savior-soldier on the body of the so-called protected.

Bare life and its biopolitical conceptualizations remain problematic forms of labeling. To equate life within a war zone to bare life or homo sacer assists in the erasure of life's complexities (even within a camp or zone of indistinction). The complicated and multifaceted layers of living bodies refusing to submit to bare life by way of their own alternative forms of bios (which may also be unrecognizable to those who bring forth aid/assistance/development) must also inform our discussions and critiques of spatialized exception. Identifying lives in war zones or displacement camps as bare life discursively enables the reduction of these human lives from a qualitative understanding to a quantifiable sum-as a the measurement of biopolitics imagined and enacted by international agents (ie military or aid/development). This scenario situates displaced bodies as a site of perpetual potentiality-living corpses on the precipice of survival, suffering, or savior.

\section{Summary and Conclusions}

Aid/development in contemporary Afghanistan illustrates disparate historical trends with common intersecting claims towards aiding and improving the lives of Afghans. These commonalities posit women's bodies as a central site for articulating and 
orchestrating power claims through discourses of freedom and liberation, protection and savior. The symbolic and material controls over women's bodies are a continual aspect of geopolitics and neoliberal economics. The spatial representations of Afghans as occupying a space of continued exception reduced to bare life, positions militarized geopolitics (to kill with impunity) and geo-economics as the site for both capital accumulation through aid dollars, and potential transference to full proper life (bios) as envisioned by the "benevolent" donor.

The collateralization of death places a monetary value on life-quantifying individual lives by way of these reductions. The civilian Afghan death is not, however, quantified in a sense of body counts (see Hyndman 2007), but rather as a form of living death, now dead, and monetarily compensated; therefore, reduced to a mere sum of capital value. Both the amount and distribution of capital for this death is determined by the executioner, and illustrates a turn in US military policy in Afghanistan that now links civilian deaths to the loss of Afghan "hearts and minds". This, of course, sets up another set of geopolitical and imperial assumptions.

Defining bare life requires a partial perspective and assumptive reduction of full life. This reduction allows for the potentialities of life (currently defined as bare) towards transference to a full and proper life, as determined through aid/development. In the Afghan case, the reduction and gendering of bare life also provides a primary site for organizations (and some individuals) to accumulate capital in order to perform the expected transference. Bare life economies (of aid/development) rely on this reductionism. The economics of bare life politically rescale the abstract bodies of civilian (living dead or collateralized death) by intimately conceptualizing the body as a site from which to articulate human rights most basic and situate the development "expert" as the mode of transference from bare to "properly modern" political life.

The geopolitical focus on Afghan woman as a prime site for western saving and processed through aid/development as a site of capital accumulation also illustrates the spaces between exclusion and inclusion, banishment and so-called "freedom". The double meaning of the sovereign ban (as excluded and open and free to all) represents the spaces of negotiation between the non-familial sovereignty as "freedom" and the freedom from sovereign control, security, and a collective conception of rights within Afghan kinship structures. Family structures exemplify strength and autonomy through women's bodies by protecting "her" from exclusion. Conversely, international aid/development focuses on "saving" Afghan women through their unveiling, political and economic participation in and acceptance of "modernity" and capitalist "freedoms". Both cases morphologize women's bodies as a symbolic measure of protection/saving. The tensions, double meanings and experiences of the ban illustrate the intricately woven complications that mark gendered bodies as representational fuel for biopolitics at multiple geopolitical scales.

I argue against placing bare life as an embodied representation of spaces (such as Afghanistan or body-as-woman). This discursive reductionism of full life stripped bare functions as bio-geo-political "life-support". This engages humanitarian aid by assuming that proper life (bios) will be achieved only through the mechanisms of international aid/development, which subsequently labels existing Afghan lives as 
bare (or lacking) rather than full, complex, and proper in ways that are outside (or excluded from) the quantifiable western imaginary. Bare life reductionism is a central site for the hierarchical re-deployment of "rights", which are infused with and bounded by the tentacles of political power, social engineering, and capital exchange. Identifying the spatial representations of bare life as war's abstractions or the gendered corporeal substance of geopolitics risks adding to the continued discursive erasure of human life complexities, complications, and alternative forms of bios that are continually produced and reproduced in these places.

\section{Acknowledgements}

Thank you to Wendy Larner for her editorial assistance and the anonymous reviewers for their helpful suggestions. A grant from the Rockefeller Center at Dartmouth College was instrumental in funding this research.

\section{Endnotes}

1 For example, secondary schools and most departments at Kabul University had international sponsors, therefore, the donors, rather than faculty or students, dictated the growth of each faculty/department (Rubin 2002).

2 The PDPA, founded in 1965, in 1967 split into two factions: Parcham (banner) and Khalq (masses). They reunited in 1977 with assistance from the USSR and the Indian Communist Party, leading to the Saur (April) Revolution.

${ }^{3}$ Najibullah ruled until the fall of the Soviet Union in 1992. He sought refuge in a UN compound, but was prevented from going into exile. He was publicly beaten and executed by the Taliban in 1996.

4 In order to ensure the confidentiality of the responses and information provided for this study, job descriptions are used rather than names for each participant and their specific affiliations are not included.

5 The predominance of English as a primary language of communication (despite the diversity of location and languages among the international and Afghan populations) is largely attributed to the role of the USA as the leading donor country and largest military presence.

6 For more on the Karzai government and US nation building, see Rashid (2008).

7 The highest paid international jobs range from $\$ 15,000$ to 30,000 per month.

8 This signification is represented on the body through corporeal dress-veil or chadori/burqa, and may also be accompanied by a mahram - a close male relative.

9 Due to low rates of literacy, large gaps in education due to the Taliban, displacement, and family concerns that women will be harassed in an international work place, women (particularly young women) remain a limited source of human capital within international workspaces.

\section{References}

Abirafeh L (2009) Gender and International Aid in Afghanistan: The Politics and Effects of Intervention. Jefferson, NC: McFarland

Abu-Lughod L (2002) Do Muslim women really need saving? American Anthropologist 104:783-790

Adamec L W (2003) Historical Dictionary of Afghanistan (third edition). Oxford: The Scarecrow Press

Agamben G (1995) Homo Sacer Sovereign Power and Bare Life. Stanford: Stanford University Press

Agamben G (2005) State of Exception. Chicago: University of Chicago Press 
Alarcon N, Kaplan C and Moallem M (1999) Introduction: Between woman and nation. In C Kaplan, N Alarcon and M Moallem (eds) Between woman and nation: Nationalisms, transnational feminisms, and the state (pp 1-16). Durham, NC: Duke University Press

Atmar M H (2001) Politicization of humanitarian aid and its consequences for Afghans. Disasters 25(4):321-330

Azarbaijani-Moghaddam S (2006) Women's Groups in Afghan Civil Society: Women and Men Working towards Equitable Participation in Civil Society Organizations. Kabul: Research Conducted for Counterpart International. USAID

Azarbaijani-Moghaddam S (2009) The arrested development of Afghan women. In J A Their (ed) The Future of Afghanistan (pp 63-72). Washington DC: United States Institute for Peace

Barakat S and Wardell G (2002) Exploited by whom? Third World Quarterly 23:909-930

Barfield T (2004) Radical political Islam in an Afghan context. Asia Program Special Report (pp 15-27). Woodrow Wilson International Center for Scholars

Belcher O, Martin L, Secor A, Simon S and Wilson T (2008) Everywhere and nowhere. Antipode 40(4):499-503

Benería L (2003) Gender, Development and Globalization. New York: Routledge

Bondi L and Laurie N (2005) Introduction. In N Laurie and L Bondi (eds) Working the Spaces of Neoliberalism (pp 1-8). Oxford: Blackwell

Butler J (2004) Precarious Life: The Powers of Mourning and Violence. London: Verso

Cockburn C (2001) The gendered dynamics of armed conflict and political violence. In C Moser and F Clark (eds) Victims, Perpetrators or Actors? Gender, Armed Conflict and Political Violence (pp 13-29). New Delhi: Kali for Women

Coleman L (2007) The gendered violence of development. Political Studies 9:204219

Davis D K (2005) A space of her own. In G W Falah and C Nagel (eds) Geographies of Muslim Women: Gender, Religion and Space (pp 68-90). New York: Guilford Press

Denike M (2008) The human rights of others. Hypatia 23:95-121

De Waal A (1998) Famine Crimes: Politics \& the Disaster Relief Industry in Africa, Bloomington, IN: Indiana University Press

Douzinas C (2007) The many faces of humanitarianism. Parrhesia 2:1-28

Duffield M (2001) Global Governance and the New Wars: The Merging of Development and Security. London: Zed Books

Dupree L (1980) Afghanistan. Oxford: Oxford University Press

Edwards D (1987) Origins of the anti-Soviet jihad. In G M Farr and J G Merriam (eds) Afghan Resistance The Politics of Survival. Boulder: Westview Press

Edwards D (2002) Before Taliban: Genealogies of the Afghan Jihad. Berkeley: University of California Press

Enloe C (1989) Bananas, Beaches \& Bases: Making Feminist Sense of International Politics. Berkeley: University of California Press

Enloe C (2000) Maneuvers. Berkeley, CA: University of California Press

Fluri J (2009) Foreign passports only: Geographies of post conflict work in Afghanistan. Annals of the Association of American Geographers 99(5):986-994

Forsythe D P (2005) The Humanitarians: The International Committee of the Red Cross. Cambridge: Cambridge University Press

Goodhand J (2006) Aiding Peace? The Role of NGOs in Armed Conflict. Boulder, CO: Lynne Rienner Publishers

Gregory D (2004) The Colonial Present: Afghanistan, Palestine, Iraq. New York: Wiley-Blackwell

Hancock G (1989) Lords of Poverty: The Power, Prestige, and Corruption of the International Aid Business. New York: The Atlantic Monthly Press

Hannah M (2006). Torture and the ticking bomb. Annals: Association of American Geographers 96:622-640

Hardt M and Negri A (2004) Multitude: War and Democracy in the Age of Empire. New York: Penguin

Hunt K (2002) The strategic co-optation of women's rights. International Feminist Journal of Politics 4:116-121

Hunt L (2007) Inventing Human Rights: A History. New York: WW Norton \& Company. 
Hyndman J (2007) Feminist geopolitics revisited: Body counts in Iraq. The Professional Geographer 59:35-46

IRIN (2005) Afghanistan: New code of conduct to regulate NGOs. 31 May, http://www.irinnews.org/report.aspx?reportid=28641 (last accessed 14 September 2008)

Jaquette J S and Summerfield G (2006) Women and Gender Equity in Development Theory and Practice: Institutions, Resources, Mobilization. Durham: Duke University Press

Johnson C and Leslie J (2002) Afghans have their memories. Third World Quarterly 23:861-874 Johnson C and Leslie J (2004) Afghanistan the Mirage of Peace. London: Zed Books

Kabeer N (1994) Reversed Realities: Gender Hierarchies in Development thought. London: Verso Kandiyoti D (1988) Bargaining with patriarchy. Gender and Society 2:274-290

Kandiyoti D (2007) Old dilemmas or new challenges? Development and Change 38:169-199

Katz C (2004) Growing Up Global: Economic Restructuring and Children's Everyday Lives. Minneapolis: University of Minnesota Press

Kennedy D (2009) Selling the distant other. Journal of Humanitarian Assistance, http://jha.ac/2009/02/28/selling-the-distant-other-humanitarianism-and-imageryethical-dilemmas-of-humanitarian-action (last accessed 14 September 2009)

Kothari U (2005) Authority and expertise. Antipode 37:425-446

Laurie N, Andolina R and Radcliffe S (2005) Ethnodevelopment. Antipode 37(3):470-496

Leebaw B (2007) The politics of impartial activism. Perspectives on Politics 5:223239

Mahmood S (2005) Politics of Piety: Islamic Revival and the Feminist Subject. Princeton: Princeton University Press

McKinnon K (2000) Postdevelopment, professionalism, and the politics of participation. Annals of the Association of American Geographers 97:772-785

Minca C (2007) Agamben's geographies of modernity. Political Geography 26: 78-97

Mindry D (2001) Nongovernmental organizations, grassroots, and the politics of virtue. Signs 26:1187-1211

Mitchell K (2006) Geographies of identity: The new exceptionalism. Progress in Human Geography 30:95-106

Mohanty C T (2004) Feminism without Borders: Decolonizing Theory, Practicing Solidarity. Durham: Duke University Press

Naghibi N (2007) Rethinking Global Sisterhood: Western Feminism and Iran. Minneapolis: University of Minnesota Press

Olds K, Sidaway J D and Sparke M (2005) White death. Environment and Planning D: Society and Space 23:475-479

Oza R (2006) The Making of Neoliberal India: Nationalism, Gender, and the Paradoxes of Globalization. New York: Routledge

Petchesky R P and Laurie M (2007) Gender, health and human rights in spaces of political exclusion. Background paper prepared for the Women and Gender Equity Knowledge Network of the WHO Commission on Social Determinants of Health

Rashid A (2008) Descent into Chaos: The United States and the Failure of Nation Building in Pakistan, Afghanistan, and Central Asia. New York: Viking

Redfield P (2005) Doctors, borders, and life in crisis. Cultural Anthropology 20(3):329-361

Roberts S, Secor A and Sparke M (2003) Neoliberal geopolitics. Antipode 35(5):826-897

Roy O (1994) From Holy War to Civil War. Princeton: Princeton University Press

Rubin B (2002) The Fragmentation of Afghanistan: State Formation and Collapse in the International System. New Haven: Yale University Press

Sangtin Writers \& Nagar R (2006) Playing with Fire: Feminist Thought and Activism through Seven Lives in India. Minneapolis: University of Minnesota Press

Saunders K (2002) Feminist Post-Development Thought: Rethinking Modernity, Post-Colonialism and Representation. London: Zed Books

Shannon R (2009) Playing with principles in an era of securitized aid. Progress in Development Studies 9:15-36

Spivak G (1987) In Other Worlds: Essays In Cultural Politics. New York: Menthuen 
Suhrke A (2007) Reconstruction and modernization: The "post-conflict" project in Afghanistan. Third World Quarterly 28:1291-1308

Sylvester C (2006) Bare life as a development/postcolonial Problematic. Geographical Journal 176:66-77

Whitlock G (2007) Soft Weapons: Autobiography in Transit. Chicago: University of Chicago Press

Woodward S L (2001) Humanitarian war. Disasters 25:331-334

Zulfacar M (2006) The pendulum of gender politics in Afghanistan. Central Asian Survey 25:27-59 